\title{
INFLUENCE OF TECHNOLOGY CONDITIONS FOR THE QUALITY OF MODERN OXYGEN MATERIALS
}

\begin{abstract}
The subject of the study was influence of technology conditions for the quality of modern oxygen materials. Analysis was focused on identification defects/ nonconformities which appear during the production process. The Ishikawa Diagram was used to definition the structure of defects/nonconformities product, while the FMEA method was used to quantify the causes of nonconformity.
\end{abstract}

Keywords: Ishikawa, FMEA, technology condition, oxygen materials.

\section{Ceramic oxygen materials and their properties}

Ceramic oxygen materials belong to group of engineering ceramic, which dynamically develops due to wide application and advantageous properties in many areas technology and materials engineering. Can be distinguish a few basic modification of modern oxygen materials, due to the addition to their composition oxygen reliable for improvement specific properties. Model ferroelectric wide describe in literature which is barium titanate with chemical formula $\mathrm{BaTiO}_{3}$ shows number of interesting properties e.g. temperature Currie is $120-130^{\circ} \mathrm{C}$, piezoelectric module $\mathrm{d}_{33}$ is $190 \cdot 10^{-12}$ C/N (GOU Q. 2012), electromechanical coupling factor around 0.5 and high dielectric constant, which is especially desirable feature in case of electronic e.g. capacitors (HSIAO-LiN W. 2002, NiEPCE J.C., HAuSSONNE J.M. 1994). Doping aluminium oxide $\mathrm{Al}_{2} \mathrm{O}_{3}$ cause high hardness, corrosion resistance even at high temperatures; widely use e.g. in isolators (CASTEL A. 1990). Another worthy of attention material is zirconium dioxide $\mathrm{ZrO}_{2}$. It causes obtaining high strength and low thermal conductivity (BOCH P., NIEPCE J.C. 2007). However, high thermal conductivity which is very important in areas of electronic and energetic, where core coils was produced, is characteristic for beryllium oxide with chemical formula $\mathrm{BeO}$ (CORMAN G.S. 1992). Nowadays modern oxygen materials are alternative for materials contains lead, which is unwanted because of toxically properties, due to the 2006 EU directive (Restriction of Hazardous Substances (2002/95/EC)), according to which directive on the restriction of the use of certain hazardous substances in electrical and electronic equipment. The aim of this

\footnotetext{
${ }^{1}$ PhD Eng., Pedagogical University of Cracow, e-mail: pczaja@up.krakow.pl

${ }^{2}$ Eng., Pedagogical University of Cracow, e-mail: adrianwegrzyn93@ gmail.com

${ }^{3}$ MSc, Pedagogical University of Cracow, e-mail: kkluczewska@up.krakow.pl
} 
research is approximation influence of technology conditions for the quality of modern oxygen materials.

\section{Structure of technological process incorrect}

Ishikawa diagram was used to identify the causes of defects/nonconformities. It is one of the most used method in the process of quality management. It contents is a graphical presentation of the interrelations of causes which leads to specification problem. By analyzing the diagram, we can isolate the most important causes that affect the occurrence of defects/nonconformities and identify corrective and preventive actions (WOLNIAK R., SKOTNICKA B. 2008, BORKOWSKI S. 2004).

Ishikawa diagram (WOLNIAK R., SKOTNICKA B. 2008, BORKOWSKI S. 2004) was prepared for the possibility of defects/inconsistencies shown in Fig. 1. The presented diagram grouped the causes of the problems and illustrated the interrelationships between them. During to the analysis, it can be observed the two biggest causes for defects/incompatibilities are: method (40\%) and material (30\%). On this basis, we can identify the main sources causing the occurrence of undesirable effects:

- errors during the preparatory process,

- lack of control over some processes,

- high dependence on the skill of the performer,

- poorly adapted apparatus,

- electrical and temperature characteristics,

- chemical composition.

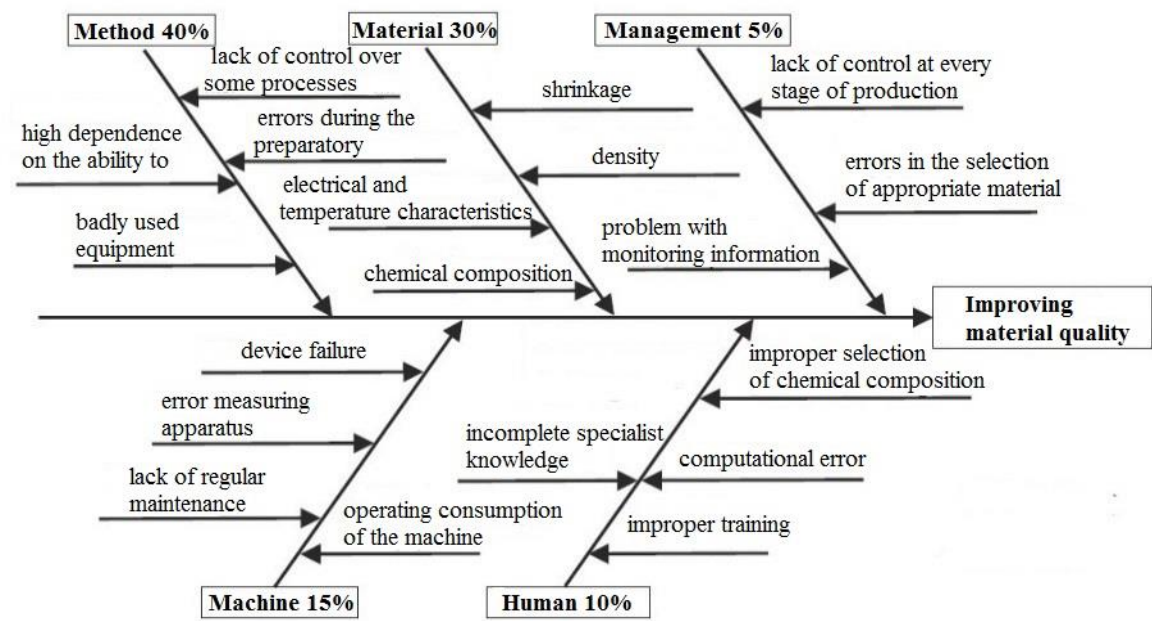

Fig. 1. Ishikawa diagram.

Source: own study 
Identification of the most important causes allows to develop a range of activities that will improve the quality and avoid/compensate for defects/incompatibilities in modern oxide materials.

For this purpose, corrective action were proposed such as:

- precise control over the preparation of modern oxide material at an early stage,

- training of employees in the method of production,

- maintenance and adjustment of the equipment prior to commencement of production.

\section{Quantification of causes of defects/nonconformities using the FMEA method}

FMEA method (BORKOWSKI S. 2004, BORKOWSKI S., KONSTANCIAK M. 2011) (socalled analysis of causes, effects and defects) is one of the quality management methods. The purpose of FMEA is to identify specific defects/nonconformities of a production process and eliminate or minimize the effects. Could be achieve this by determining the cause and effect sequence of potential defects/nonconformities. FMEA allows to continually improve product and process through systematic can analyses and error correction.

Table 1. Types of defects/nonconformities

\begin{tabular}{|c|c|c|c|c|c|c|c|c|}
\hline Type of error & $\begin{array}{c}\text { The effects of } \\
\text { the error }\end{array}$ & $\begin{array}{c}\text { Causes of } \\
\text { terror }\end{array}$ & $\begin{array}{c}\text { Take control } \\
\text { measures }\end{array}$ & $\mathbf{Z}$ & $\mathbf{W}$ & $\mathbf{R}$ & $\mathbf{L P R}$ & $\begin{array}{c}\text { Corrective } \\
\text { action }\end{array}$ \\
\hline $\begin{array}{c}\text { Wrong } \\
\text { chemical } \\
\text { composition }\end{array}$ & $\begin{array}{c}\text { Inadequate } \\
\text { temperature and } \\
\text { electrical } \\
\text { properties }\end{array}$ & $\begin{array}{c}\text { Errors during } \\
\text { the preparatory } \\
\text { process }\end{array}$ & $\begin{array}{c}\text { Increased control } \\
\text { during the } \\
\text { preparatory process }\end{array}$ & 10 & 10 & 5 & 500 & $\begin{array}{c}\text { Fabrication } \\
\text { from scratch }\end{array}$ \\
\hline $\begin{array}{c}\text { Material } \\
\text { damage }\end{array}$ & $\begin{array}{c}\text { Cracks, } \\
\text { mechanicaldam } \\
\text { age }\end{array}$ & $\begin{array}{c}\text { Poorly adjusted } \\
\text { engineratios }\end{array}$ & $\begin{array}{c}\text { Adaptation of the } \\
\text { apparatus before } \\
\text { commencement of } \\
\text { the production stage }\end{array}$ & 8 & 3 & 4 & 96 & $\begin{array}{c}\text { Fabrication } \\
\text { from scratch }\end{array}$ \\
\hline $\begin{array}{c}\text { Wrong } \\
\text { method }\end{array}$ & $\begin{array}{c}\text { Possibility of } \\
\text { undesirable } \\
\text { material } \\
\text { properties }\end{array}$ & $\begin{array}{c}\text { No adequate } \\
\text { training }\end{array}$ & $\begin{array}{c}\text { Adhere to guide lines } \\
\text { during the method }\end{array}$ & 6 & 5 & 2 & 60 & Employee \\
training
\end{tabular}

Source: own study

By creating an FMEA analysis, was determine the risk incidence/non-compliance, customer relevance, and probability. Used the formula for calculating LPR for this purpose (KMENTA S., ISHII K. 2004) (Priority risk number)), critical error shave also been identified and corrective actions have been identified. 
Where: LPR - Risk Priority Number,

$$
\begin{aligned}
& \mathrm{Z} \text { - Severity, } \\
& \mathrm{W} \text { - Detection, } \\
& \mathrm{R} \text { - Occurrence. }
\end{aligned}
$$

This shown in Table 1. From the presented results, it is obvious that the highest risk of defect/nonconformity is related to a fault, that induce the wrong chemical composition $(\mathrm{LPR}=500)$, another defect on medium level is material damage $(\mathrm{LPR}=96)$, the smallest priority number received the wrong method $(\mathrm{LPR}=60)$. As we see errors during the preparatory process, there is a great risk of defect / non-compliance that cannot be eliminated.

\section{Example of defects/incompatibilities in modern oxide material}

The misalignment of the uniaxial pressure with respect to the pressure surface may result in delamination (or cracks) at the sintering stage and which may be invisible at the tablet compression stage. Fig. 2 present sample $\mathrm{K}_{0.5} \mathrm{Bi}_{0.5} \mathrm{TiO}_{3}$ without any defect/incompatibilities The Fig. 3 and Fig. 4 show a sample of oxide ceramics of the pattern $\mathrm{K}_{0.5} \mathrm{Bi}_{0.5} \mathrm{TiO}_{3}$ which was subjected to too much force pressure during ironing in relation to dimensions. The effect of the surface defect could be observed only after the sintered finish and the use of abrasive glycerol, which fulfilled the penetrating role here.

On Fig. 3 we can staging the surface of the sample after sintering with enlargement and surfaced effect in the form of delamination (or cracks). Fig. 4 shows the opposite side of this sample with the enlargement of the a fore mentioned fault.

Fig. 5 present defect induced by too much pressure during uniaxial ironing Fig. 6 show a sample with cracks which appear after sintered process. The effect of the surface defect could be observed without use penetrant. This sample have not been grinding. Fig. 7 and Fig. 8 present internal stress in different sample of oxide ceramics $0.98\left(\mathrm{~K}_{0.5} \mathrm{Bi}_{0.5}\right) \mathrm{TiO}_{3}+0.02 \mathrm{SrTiO}_{3}$. We can observed interior (Fig. 7) and outside (Fig. 8) sample. 
Zeszyty Naukowe

No 1(6) 2017

Quality. Production. Improvement

s. $39-46$
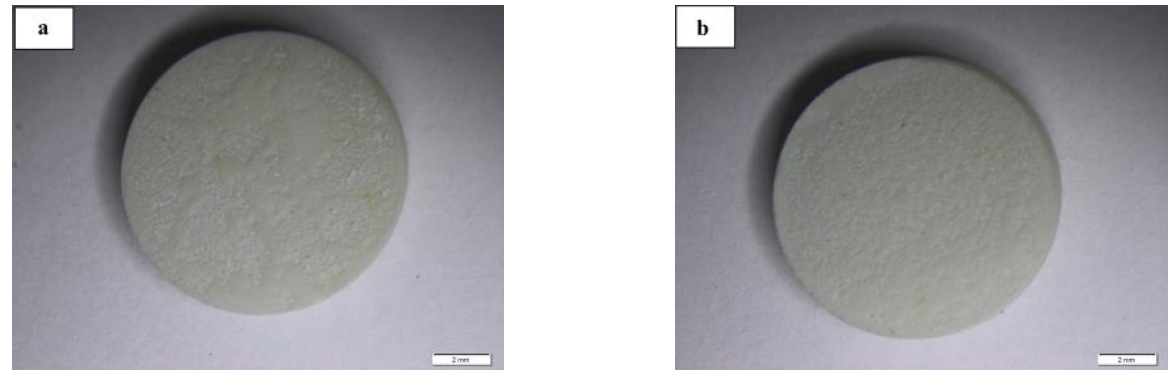

Fig. 2. Sample without defect/incompatibilities.

Source: own study
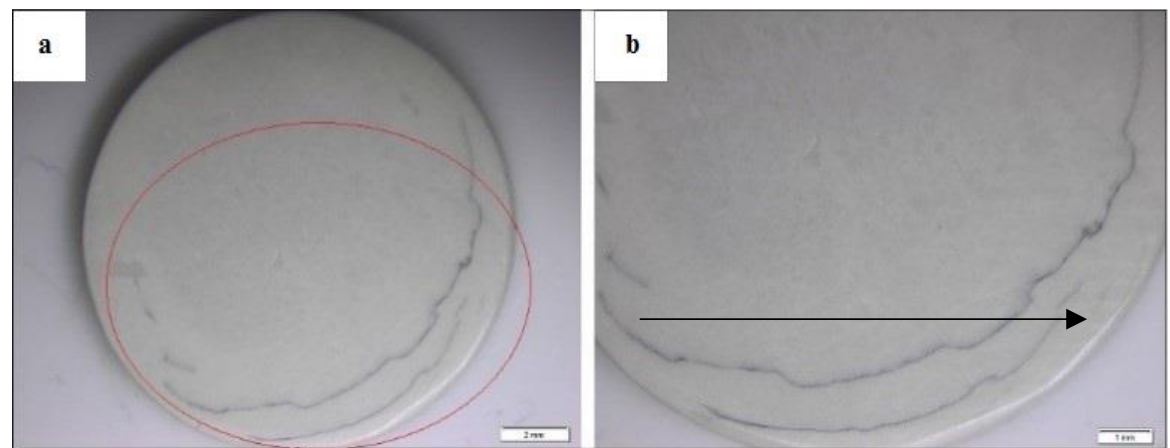

Fig. 3. Surface defect of the sample. a) sample with defects/incompatibilities, b) zoom of defects/incompatibilities.

Source: own study

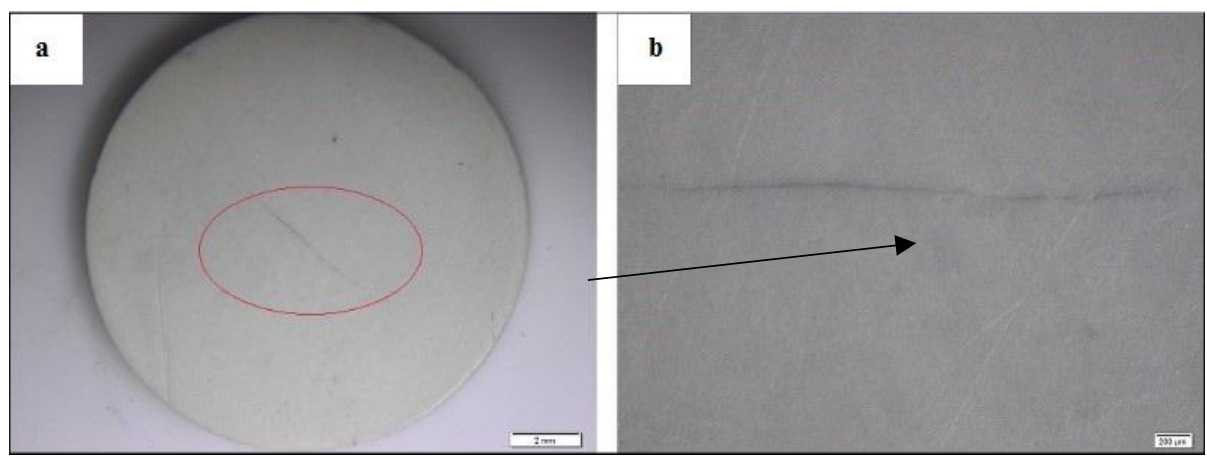

Fig. 4. Surface defect of the reveres sample: a) sample with defects/incompatibilities, b) zoom of defects/incompatibilities.

Source: own study 


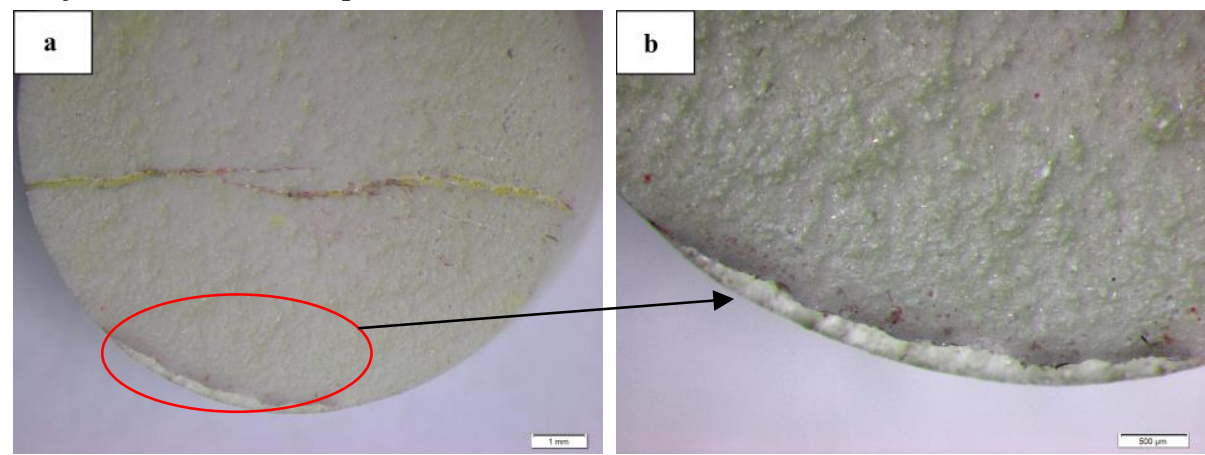

Fig. 5. a) defect induced by too much pressure during uniaxial ironing process, b) zoom of defect.

Source: own study

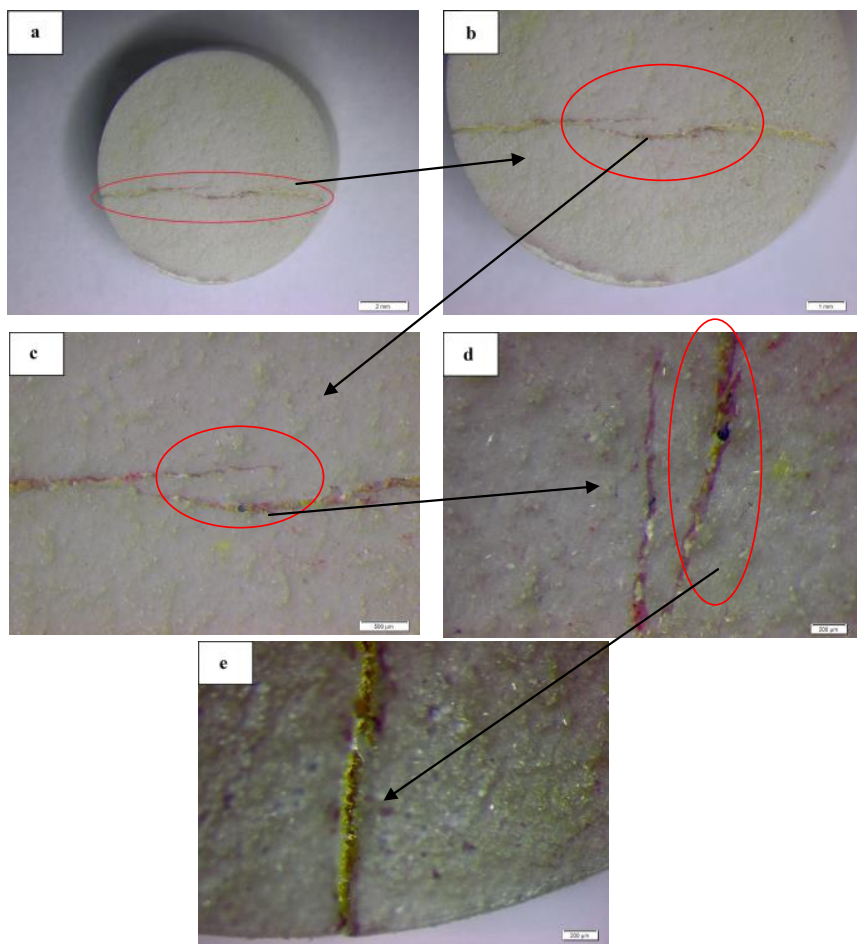

Fig. 6. Surface defect of the sample without penetrant. Cracks established after the sintered. a) present cracks which establish after sintered. b), c), d) and e) different zoom of established crack.

Source: own study 


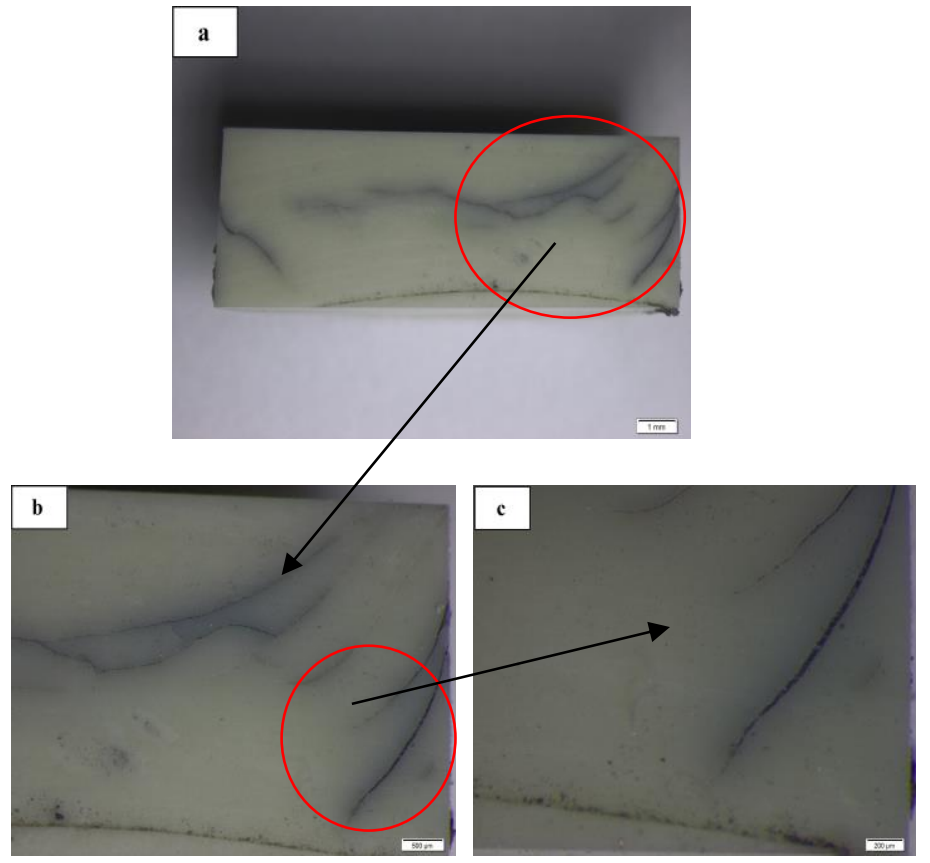

Fig. 7. Internal stress on interior side of sample, a) present internal stress, b), c) zoom of internal stress.

Source: own study

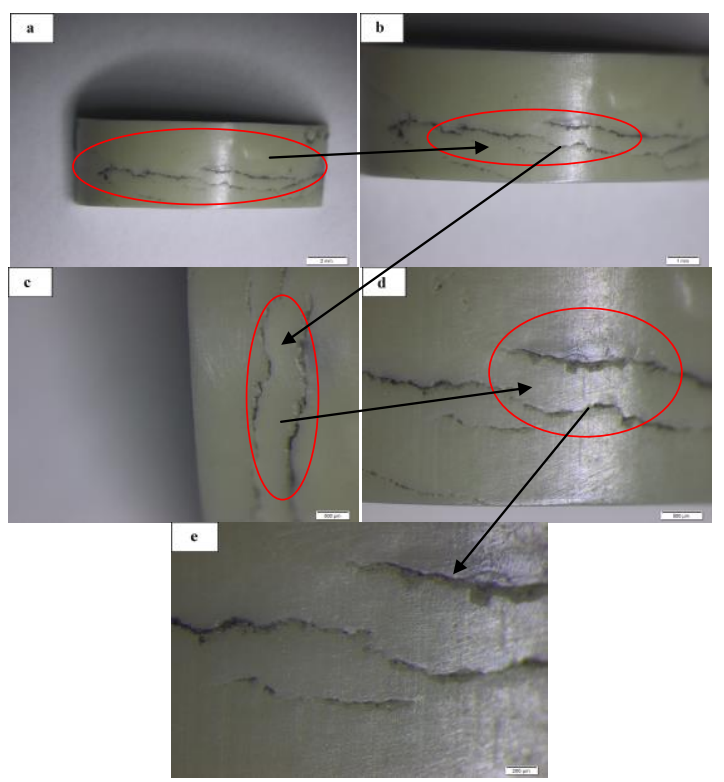

Fig. 8. Internal stress on outside side of sample, a) present internal stress, $b), c), d), e)$ zoom of internal stress.

Source: own study 


\section{Bibliography}

1. Boch P., NiePCe J.C. 2007. Ceramic Materials: Processes, Properties and Applications.

2. BoRKowsKi S. 2004. Mierzenie poziomu jakości. Wydawnictwo Wyższa Szkoła Zarządzania i Marketingu w Sosnowcu. Sosnowiec.

3. BorkowsKi S., KonstanciaK M. 2011. Production Improvement. Editing and Scientific Elaboration Borkowski S., Konstanciak M., TRIPSOFT, Trnava.

4. CASTEL A. 1990. Les alumines et leurs applications, Nathan.

5. Cormang. S. 1992. J. Am. Ceram. Soc., 75, 71.

6. HSIAO - LIN W. 2002. Structure and dielectric properties of Perovskite - Barium Titanate (BaTiO3). Submitted in Partial Fulfillment of Course Requirement for MatE 115, Fall, San Jose State University.

7. KMENTA S. ISHII K. 2004. "Scenario-Based Failure Modes and Effects Analysis Using Expected Cost". Journal of Mechanical Design. 126 (6): 1027

8. NiEPCE J.C., HAussonne J.M. 1994. BaTiO3: Matériau de Base pour les Condensateurs Céramiques. Vol. 1 I-Les condensateurscéramiques à base de BaTiO3; II-Structures et propriétés de BaTiO3; Vol. 2 III-Les méthodesd'élaboration de BaTiO3; IV-Réalisation des condensateurs: contraintesliées aux matériaux et aux technologies, EditionsSeptima, Collection Forceram, Restriction of Hazardous Substances (2002/95/EC).

9. Suchuan Z.,Guorong L., Aili D., Tianbao W., QIngrui Y. 2006. Ferroelectric and piezoelectric properties of $(\mathrm{Na}, \mathrm{K})_{0.5} \mathrm{Bi}_{0.5} \mathrm{TiO}_{3}$ lead free ceramics.

10. QIAN Gou 2012. Enhanced d33 value of BiO.5NaO.5TiO3 (Ba0.85Ca0.15)(Ti0.90ZrO.10)O3 lead-free ceramics Journal of Alloys and Compounds.

11. WolniaK R., SKotNiCKA B. 2008. Metody i narzędzia zarządzania jakościa. Gliwice. 